January 2009

\title{
FINANCING AND RISK MANAGEMENT TECHNIQUES IN GREEN FIELD PROJECTS UNDER PUBLIC, PRIVATE PARTNERSHIP (PPP) MODEL: A CASE STUDY OF RAJIV GANDHI INTERNATIONAL AIRPORT (RGIA) LTD, HYDERABAD.
}

Sarbesh Mishra

National Institute of Construction Management and Research (NICMAR), sarbeshmishra@nicmar.ac.in

Malay Kumar Mohanty

Interscience Institute of Management and Technology (IIMT), drmalaymohanty@yahoo.co.in

Follow this and additional works at: https://www.interscience.in/imr

Part of the Business Administration, Management, and Operations Commons, and the Human Resources Management Commons

\section{Recommended Citation}

Mishra, Sarbesh and Mohanty, Malay Kumar (2009) "FINANCING AND RISK MANAGEMENT TECHNIQUES IN GREEN FIELD PROJECTS UNDER PUBLIC, PRIVATE PARTNERSHIP (PPP) MODEL: A CASE STUDY OF RAJIV GANDHI INTERNATIONAL AIRPORT (RGIA) LTD, HYDERABAD.," Interscience Management Review. Vol. 2 : Iss. 1 , Article 6.

DOI: 10.47893/IMR.2009.1021

Available at: https://www.interscience.in/imr/vol2/iss1/6

This Article is brought to you for free and open access by the Interscience Journals at Interscience Research Network. It has been accepted for inclusion in Interscience Management Review by an authorized editor of Interscience Research Network. For more information, please contact sritampatnaik@gmail.com. 


\title{
FINANCING AND RISK MANAGEMENT TECHNIQUES IN GREEN FIELD PROJECTS UNDER PUBLIC, PRIVATE PARTNERSHIP (PPP) MODEL: A CASE STUDY OF RAJIV GANDHI INTERNATIONAL AIRPORT (RGIA) LTD, HYDERABAD.
}

\author{
Sarbesh Mishra, \\ National Institute of Construction Management and Research (NICMAR) \\ NICMAR's CISC, NAC Campus, P.O - Kondapur, At - Hyderabad, PIN - 500 084. INDIA. \\ E-mail - sarbeshmishra@nicmar.ac.in \\ Prof. Malay Kumar Mohanty, \\ Interscience Institute of Management and Technology (IIMT) \\ Dist - Khurda, PIN - 752 024. INDIA. \\ E-mail - drmalaymohanty@yahoo.co.in
}

ABSTRACT

PPP projects have brought a big change in Indian Infrastructure Industry. There was not only a dramatic turnaround in the time taken for completion of projects but also a big change in quality of the projects. This change was because of involvement of a private player in the project. Though projects in the range of 500 crores, 1000 crores or even more than that was earlier handled by government departments but they always lacked with timely delivery and quality of projects. This was because of lack of planning and even because of lack of modern day tracking of projects. Now this gap was merged with the entry of a private player. There are glaring examples that this model has been a big success, be it RGIA of Hyderabad or modernization of Delhi and Mumbai airports, each of these projects has been a big success. It's not only airport projects that has become successful even there are a lot of projects in road sector, port sector which have been completed in this model. The major issue with big infrastructure projects has been financing of these projects. Since in a PPP model private player also takes up the responsibility of financing the project with adequate support from government overall funding of the project becomes easier. But the problem does not seem to end over here because the private player which takes the responsibility of financing the project during initial stage also bears the risk of revenue generation which might be a big concern during operational phase. If the actual revenue falls short of projected revenue than the ROI will have a severe impact.

In order to counteract these problems associated with various PPP models several risk mitigation strategies are adopted to safeguard both the parties in a better way. Though India has taken a huge step forward by awarding several projects in this PPP model still there is a long way to go in terms understanding the pros and cons of PPP model and how well it can be adopted in Indian scenario.

\section{KEYWORDS}

PPP, VGF, O\&M, ROI, Risk, Concession, SPV, Debt, Green Field, Brown Field, Passenger, Traffic

\section{INTRODUCTION}

India as an economy has been growing at a faster rate than any of the developed countries in the world and the infrastructure has been one of the reasons for this growth. A good infrastructure always has a big impact in any countries growth. India is the fourth largest economy in the world with a GDP of 1242.8 billion US\$. Between 2000 and 2008 India’s GDP rate doubled from 5.75\% to $9.3 \%$ in 2007 before tapering to a robust $7.9 \%$ in 2008 .

Total estimate of Indian Infrastructure was estimated at 5\% of GDP in 2006-07.To achieve a GDP growth rate of 9\% set by the planning commission the GCF in infrastructure should rise to $9 \%$ of GDP. The above figures give a clear picture of what is the role infrastructure plays in countries growth. The below mentioned graph will show how the role of infrastructure has been increasing on a YOY basis and how it will increase in the future years.

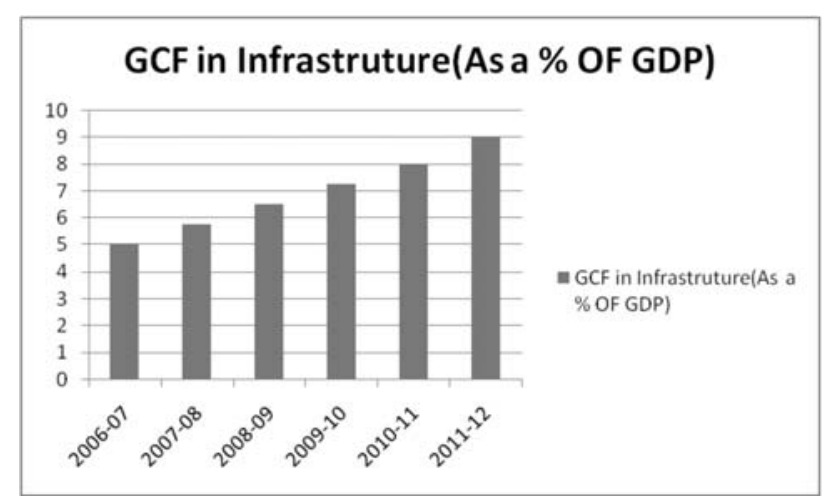

Graph 1 - YOY Infrastructure Growth

With the above rise it is clearly visible that the role of private party will rise, but the public sector will play a dominant role in financing of infrastructure projects.

So to push the growth rate in India, infrastructure too has to develop simultaneously not with the same but with a higher rate. Hence to meet the needs of the above mentioned situation PPP concept will definitely play a major role.

ADVANTAGES OF PUBLIC, PRIVATE PARTNERSHIP MODEL 
FINANCING AND RISK MANAGEMENT TECHNIQUES IN GREEN FIELD PROJECTS UNDER PUBLIC, PRIVATE PARTNERSHIP (PPP) MODEL: A CASE STUDY OF RAJIV GANDHI INTERNATIONAL AIRPORT (RGIA) LTD, HYDERABAD.

PPP is a "partnership between various public administrations on the one hand and legal persons subject to private law on the other, for the purpose of designing, planning, Constructing, financing and/or operating an infrastructure project. The key feature for a Successful PPP is the allocation of the project's risks between the public and private sector According to each party's ability to manage and bear them, without destroying the Economic Balance of the project."

The reasons postulated in support of the PPP model for infrastructure development include:

- Stimulate economic growth

- Improved and expanded infrastructure services that would not be there otherwise

- Technology transfer, training of local personal and development of national

- capital markets

- Competition and innovation

- Improved efficiency

- Faster implementation

- Relieving the government budget and borrowing

- Providing a benchmark with which to judge the public sector's performance

- Better allocation of risk between the public and private sectors

- Improve service delivery

- Improve cost-effectiveness

- Increase investment in public infrastructure

- Reduce public sector risk

- Deliver capital projects faster

- Improve budget certainty

- Make better use of assets

- Greater cost-effectiveness in managing project risks;

- Savings captured/benefits enhanced because of better time-to-delivery;

- Accesses private sector innovation and management skills;

- Lower demands on governmental operating budgets, reduced fiscal deficits;

- Better value-for-money for government and community.

\section{ADVANTAGETOLOCALGOVERNMENT}

- Value for money;

- Appropriate risk transfer to the private sector

- Early project delivery;

- Gains from innovation;

- Avoiding the need to borrow to finance infrastructure investment;

- Access to improved services.

\section{VARIOUS FEASIBLEALTERNATIVE PPPMODELS}

\section{Design-Build (DB):}

Under this model, the government contracts with a private partner to design and build a facility in accordance with the requirements set by the government. After completing the facility, the government assumes the responsibility for operating and maintaining the facility. This method is also referred to as Build-Transfer (BT).

\section{Build Own Operate (BOO):}

The government grants the right to finance, design, build, operate and maintain a project to a private entity, which retains ownership of the project. The private entity is not required to transfer the facility back to the government.

\section{Build Operate Transfer (BOT):}

The private business builds and operates the public facility for a significant time period. At the end of the time period, the facility ownership transfers to the public.

\section{Build-Own-Operate-Transfer (BOOT):}

The government grants a franchise to a private partner to finance, design, build and operate a facility for a specific period of time. Ownership of the facility is transferred back to the public sector at the end of that period.

\section{Buy Build Operate (BBO):}

The government sells the facility to the private business. The private business refurbishes and operates the facility.

\section{Design Build-Operate (DBO):}

A single contract is awarded to a private business which designs, builds, and operates the public facility, but the public retains legal ownership. 


\section{Design-Build-Maintain (DBM):}

This model is similar to Design-Build except that the private sector also maintains the facility. The public sector retains responsibility for operations.

\section{Build-Develop-Operate (BDO):}

The private business buys the public facility, refurbishes it with its own resources, and then operates it through a government contract.

\section{Build-Own-Lease-Transfer (BOLT):}

The government grants the right to finance and build a project which is then leased back to the government for an agreed term and fee. The facility is operated by the government. At the end of the agreed tenure the project is transferred to the government

\section{Contract Add and Operate (CAO):}

CAO can be said to be a contractual agreement whereby the project developer adds to an existing infrastructure facility which it rents from the government and operates the expanded project over an agreed as a period franchise. There may or may not be a transfer arrangement with regard to the added facility provided by the project developer.

\section{Develop Operate and Transfer (DOT):}

DOT can be said to be a contractual arrangement whereby favorable conditions external to the new infrastructure project which is to be built by a private developer are integrated into the arrangement by giving that entity the right to develop adjoining property, and thus, enjoy some of the benefits created by the investment such as higher property or rent values.

\section{Rehabilitate Operate and Transfer (ROT):}

ROT can be said to be a contractual arrangement whereby an existing facility is turned over to a private entity to refurbish, operate and maintain for a specific period as a franchisee, on the expiry of which, the legal title to the facility is turned over to the government. The term is also used to describe the purchase of an existing facility from abroad, refurbishing, erecting and consuming it within the host country.

\section{Rehabilitate Own and Operate (ROO):}

ROO can be said to be a contractual arrangement whereby an existing facility is turned over to the private sector for refurbishing and operation with no time limit on ownership. As long as the operator has not violated the franchise, it can continue to operate the facility in perpetuity.

\section{Lease Renovate Operate and Transfer (LROT):}

LROT can be said to be a contractual arrangement whereby an existing infrastructure facility is handed over to private, parties on lease, for a particular period of time for the specific purpose of renovating the facility and operating it for a specific period of time; on such terms and conditions as may be agreed to with the government for recovering the costs with an agreed return and thereafter, transferring the facility to the government. The Ministry of Power has adopted this route for the renovation of existing power plants.

\section{Design-Build-Operate (DBO):}

Under this model, the private sector design and builds a facility on the turn-key basis. Once the facility is completed, the title for the new facility is transferred to the public sector, while the private sector operates the facility for a specified period. This model is also referred to as Build-TransferOperate (BTO).

\section{Design-Build-Finance-Operate/Maintain (DBFO, DBFM or DBFO/M):}

Under this model, the private sector designs, builds, finances, operates and/or maintains a new facility under a long-term lease. At the end of the lease term, the facility is transferred to the public sector. In some countries, DBFO/ $\mathrm{M}$ covers both BOO and BOOT.

\section{OPERATIONALFRAMEWORK PPP'S IN INDIA}

To address various constraints in the PPP model, several initiatives have been taken by the Government of India to create an enabling framework for PPPs by addressing issues relating to policy and regulatory environment. Progressively, more sectors have been opened to private and foreign investments levy of user charges is being promoted, regulatory institutions are being set up and strengthened, and fiscal incentives are given to infrastructure projects. 
Therefore the government has come out with various initiatives such as:

o Scheme for financial support to PPP in infrastructureviability gap funding (VGF) Scheme for financing viable infrastructure projects through a special purpose vehicle (SPV)

o Indian Infrastructure Finance Company Limited (IIFCL)

o Establishment of the Indian Infrastructure Development Fund

o Empanelment of Transaction Advisers (TAs) for PPP projects

\section{Viability Gap Funding (VGF) Scheme}

The VGF Scheme of the government of India provides financial support in the form of grants to infrastructure projects undertaken on PPP mode-a capital grant at the stage of project Fully Public Fully Private Operation \&Maintenance contract Design Build Design Build Operate Lease Develop Operate Buy Build Operate Build Transfer Operate Build Operate Transfer Build Own Operate Roles, Skill Requirements, and Risks of Private Sector ranges from Low to High construction. These grants are either one time or deferred basis, and are strictly restricted for the purpose of making the projects commercially viable. The ministry of finance administers this scheme. The scheme restricts its applicability to 'infrastructure service', which includes roads and bridges, railways, seaports, airports, inland waterways, power, urban transport, water supply, sewerage, solid waste management and other physical infrastructure in urban Infrastructure projects in special economic zones, international convention centers and other tourism infrastructure projects. Another prerequisite for the applicability of the scheme is that the project should provide the infrastructure service against the payment of a predetermined tariff or user charge.

Under this scheme, the support of the government in the mode of VGF shall not Exceed 20\% of the total project costs; but the government or statutory entity may grant an additional $20 \%$, only out of its own budget.

\section{Indian Infrastructure Finance Company Limited (IIFCL)}

Indian Infrastructure Finance Company Limited (IIFCL) has been set up with the Specific mandate to play a catalytic role in the infrastructure sector by providing long-term financing to infrastructure projects in India. IIFCL raises funds both from the domestic as well as external markets on the strength of the government guarantees. An offshore SPV, Indian Infrastructure Finance Company (UK) Limited has been set up to utilize part of foreign exchange reserves for infrastructure development. Lending by IIFCL is again restricted to projects involving 'infrastructure services'. IIFCL finances only commercially viable projects. IIFCL therefore, also finances those PPP projects, which become viable after receiving the VGF. IIFCL restricts its lending to only projects implemented i.e., developed, financed and operated for the project term by a public sector company, a private sector company selected.

Under a PPP initiative, a private sector company or the project company borrowing from IIFCL should set up on a 'non resource basis' (should be a special purpose vehicle for the project). The scheme provides for option of seeking ' $n$ principle' approval for financial assistance by the sponsoring entity. Under this scheme, the actual lending is governed by appraisal of the lead bank before financial closure of projects. The lead bank is responsible for regular monitoring and periodic evaluation of project compliance with agreed milestones and performance levels especially with respect to disbursement of IIFCL funds. IIFCL provides for funding viable infrastructure projects through long term debt, or refinancing to banks and financial institutions for loans granted by them or with tenure exceeding 10 years, or any other mode, which may be from time-to-time, be approved by the government. The lead bank further takes the responsibility of disbursing the loans advanced by IIFCL and also the recovery of the same. For smooth conduct, IIFCL enters into a tripartite agreement with the lead bank and the project company for every individual project.

\section{Indian Infrastructure Project Development Fund (IIPDF)}

Quality advisory services are fundamental to procuring affordable, value-for-money PPPs. The cost of procuring these transactions advisers for the PPPs is also significant. IIPDF is corpus fund set up for the purpose of providing financial support for quality project development activities to the states and the central ministries. IIPDF has been created in the Department of Economic Affairs, Ministry of Finance, and Government of India for supporting the development of credible and bankable PPP projects that can be offered to the private sector. IIPDF is the scheme for funding to cover a portion of the PPP transaction costs, thereby reducing the impact of costs related to procurement on their budgets. IIPDF is not aimed to act as a source of grant funding for the sponsoring authorities but to assist the sponsoring authorities with up to $75 \%$ of their project development expenses. It has also been mentioned in the scheme that as the IIPDF matures with experience and time, a suitable autonomous legal structure is considered by the government for the management of the IIPDF. Therefore, 
IIPDF is to assist project that closely support the best practices in PPP project identification and preparation as set out in guidance to be issued by the Department of Economic Affairs from time-to-time.

\section{Transaction advisers for PPP Projects:}

PPPs are still in their infancy stage in India. A systematic compilation of knowledge and experiences on PPP projects across sectors, greater awareness of good examples and established procedures will certainly add execution clarity of the sponsoring entity and also will provide quality information to investors on PPP schemes and incentives.

\section{DEFINITIONOFGREENFIELDAIRPORT}

Greenfield Airport means a new airport which is built from scratch in a new location because the existing airport is unable to meet the projected requirements of traffic. The word Greenfield originates from software engineering, meaning a project which lacks any constraints imposed by prior work. Those projects which are modified or upgraded from existing facilities are called Brownfield projects India will have 35 Greenfield airports by 2012 to keep up with the growth of the civil aviation sector.

\begin{tabular}{|c|c|c|c|c|}
\hline & HYDERABAD & BANGALORE & DELLHI & MUMBAI \\
\hline Initial Capacity Per & $\begin{array}{c}\text { 5million } \\
\text { passengers }\end{array}$ & $\begin{array}{l}11.5 \text { million } \\
\text { passengers }\end{array}$ & $\begin{array}{l}37 \text { million } \\
\text { passengers }\end{array}$ & $\begin{array}{l}40 \text { million } \\
\text { passengers }\end{array}$ \\
\hline Concession Period & $30 \mathrm{yrs}$ & $30 \mathrm{yrs}$ & $30 \mathrm{yrs}$ & $30 \mathrm{yrs}$ \\
\hline Project Status & Under Operation & Under Operation & Under Construction & Under Construction \\
\hline $\begin{array}{c}\text { Year of } \\
\text { construction }\end{array}$ & October - 2005 & July - 2005 & May - 2006 & August - 2006 \\
\hline Date of operation & Mar-08 & Apri-08 & March-2010 & Not available \\
\hline Format & BOOT & BOOT & LDOT & LDOT \\
\hline Total Project cost & 2478 & 1930 & 8600 & 5800 \\
\hline
\end{tabular}

Note - 1. Projected capacity per annum. 2. Project cost in Crores (I Crore $=10$ Million $)$

\section{PROSAND CONS OF GREENFIELDAND BROWNFIELDAIRPORTS}

- A major difference between public and private airports, with respect to the capital structure, is the presence of debt. Debt constitutes about 75 -80 per cent of the total project investment in PPP airports. It is well known that the presence of debt increases the risk of bankruptcy. All things remaining the same, the risk on a PPP project which has a debt of 80 per cent at 15 per cent interest increases the project risk by 43 per cent, compared with a fully government funded project.

- The government has provided an exclusivity agreement to Greenfield projects under which no other airport can function within 70,000 sq km during the concession period. New airports can come up in the case of Brownfield airports with the concessionaire getting the right of first refusal for investing in the same. The Brownfield model thus gives more options to the government for setting up future airports depending on the demand and development of the city.

- $\quad$ The debt equity ratios are 4:1 and 3:1 for Greenfield and Brownfield projects, respectively.

- The higher debt equity ratio on a Greenfield project makes it financially more risky. On the other hand, the revenue payout to the government from Brownfield projects looks more attractive. Apart from the upfront fee, the concessionaire would pay an annual fee equivalent to 30 - 35 per cent of the projected revenue for the year. In the case of Greenfield projects, the annual fee would be just 4 per cent of the gross revenues. Therefore, from the government's perspective, Brownfield airports would form better candidates for PPP than Greenfield airports.

\section{RISKMANAGEMENT IN PPP'S}

The significance of risks in life cycle oriented projects arises from the long-term nature of the contractual arrangement and from the scope of risks linked to the steps of the value chain. In a PPP project, deliverables in planning, construction, financing, operation, maintenance and exploitation or disposal are placed in package, each of which has specific risks attached. Thus the complexity of the arrangement itself leads to increased risk exposure. The project stakeholders have to deal with many risk issues in terms of policies and regulations, documentation, financing, taxation, technical details, sub agreements, interfaces etc. starting as early as in the development stage of the project.

\section{VARIOUS TYPES OF RISKS}

- Market and revenue risks

- Design risks

- Construction risks

- Operating risks

- Financial risks

- Political risks

- Legal risks

- Environment risks

- $\quad$ Force Majeure risks

\section{RISKMITIGATION STEPSAND STRATEGIES}


FINANCING AND RISK MANAGEMENT TECHNIQUES IN GREEN FIELD PROJECTS UNDER PUBLIC, PRIVATE PARTNERSHIP (PPP) MODEL: A CASE STUDY OF RAJIV GANDHI INTERNATIONAL AIRPORT (RGIA) LTD, HYDERABAD.

\begin{tabular}{|c|c|cc|c|}
\hline STEP-1 & STEP - 2 & STEP - 3 & STEP-4 & STEP - 5 \\
\hline $\begin{array}{c}\text { IDENTIFY } \\
\text { RISK }\end{array}$ & $\begin{array}{c}\text { DETERMINE } \\
\text { SEVERITY OF RISK }\end{array}$ & $\begin{array}{c}\text { ALLOCATE THE } \\
\text { RISK }\end{array}$ & $\begin{array}{c}\text { MITIGATE } \\
\text { THE RISK }\end{array}$ & $\begin{array}{c}\text { PRICE THE } \\
\text { RISK }\end{array}$ \\
\hline $\begin{array}{c}\text { Identifying } \\
\text { the events or } \\
\text { actions which } \\
\text { affects the } \\
\text { viability of } \\
\text { the project }\end{array}$ & $\begin{array}{c}\text { In case the event occur } \\
\text { then effect of the same on } \\
\text { the cost } / \text { time of the } \\
\text { projot }\end{array}$ & $\begin{array}{c}\text { Identifying and } \\
\text { allocating the risk } \\
\text { to the party who } \\
\text { can manage it best }\end{array}$ & $\begin{array}{c}\text { considered to } \\
\text { reduce the } \\
\text { chances of the } \\
\text { event occurning }\end{array}$ & $\begin{array}{c}\text { Cost of the risk } \\
\text { needs to be } \\
\text { addressing to be } \\
\text { determined }\end{array}$ \\
\hline
\end{tabular}

\section{RISKMANAGEMENT PROCESS}

The term "risk management" stands for a controlled and systematic dealing with strategic and operational risks and can be understood in general as a systematic control of risks. The risk management seeks to identify the risks in time, to assess the risks properly, to develop appropriate risk strategies as well as to implement them in due course. Guaranteeing a lasting effectiveness and efficiency of the risk management requires a systematic and clear structure of the company and project organization as well as the embedding of a system of organizational and operational structure policies. The responsibilities are to be defined precisely and transparently and the number of the interfaces is to be reduced as much as possible. In general, the risk management can differ with regard to the dimensions and scope of the project and company. The company risk management includes all risk-related strategic and operational activities of a company which are necessary to secure its corporate planning and the prospective development. Analogously, corporate risk management is also to be applied within public management. Project risk management includes the systematic risk management of the operational project risks. Consequently, risk management is a necessary instrument for the structuring and control of projects which guarantees the successful realization of the project objectives.

Although the subsequent risk management refers to a PPP project, its structuring is influenced by the interaction between company/administrative scope and project scope. Thus through the company risk policy based on the strategic objectives and organizational guidelines, the willingness to take risk is determined and in doing so the framework for project risk management as well. As mentioned before, risk management is an ongoing process over the life cycle of the project, which starts with the project initiation and has to be observed during the total duration of the project. As shown in Figure, it can be broken down into the following activities: risk identification, risk analysis and assessment, risk allocation, risk mitigation, risk control and monitoring.
Monitoring and controlling risk is the process of implementing risk response plans (risk mitigation strategies), tracking identified risks, monitoring residual risks, identifying new risks, and evaluating risk process effectiveness throughout the project lifetime. This process occurs at every stage of risk management.

The major task of the private partner during the project life cycle is to consistently observe all risks allocated to him, to steer and to initiate adequate risk strategies in terms of reduction, avoidance, transfer or acceptance. Risk monitoring is also necessary for the public sector during the duration of the contract to avoid or to influence the retained risks in order that their financial consequences remain as low as possible. Furthermore, it can be found out whether the risk profile of the project for the time has changed and whether the risk allocation stipulated by contract has been proved to be efficient.

The project and contract management is a process for the enforcement of the agreed terms of contract and contain the control that the deliverables and performance such as implementation planning, request for approval, construction works, start-up and delivery of facility management services by the private contractors at the agreed standards stipulates. In doing so, the risks are managed as well. The contract management requires certain abilities and knowledge of the project partners. It is an advantage if the contract management committee already possesses particular knowledge about the details of negotiation at the time of conclusion of the contract and is familiar with the project team belonging to the private partner. Because it is impossible to take into account any future event by the contractual agreement, it is favourable to solve upcoming decisions and challenges at working level to prevent conflicts and recourse to arbitration.

There is the need to be aware of new developments that could impact existing risks or generate new risks within a PPP project. The change in interdependencies between project functions and risks must be continuously monitored.

Finally, the risk management process has to be completed by means of the communication concept which is to be implemented at earliest stage. Effective communication ensures that internal and external stakeholders and those responsible for implementing risk management have a clear understanding of the basis on which decisions are made, how the information flow works and why certain actions are required. 


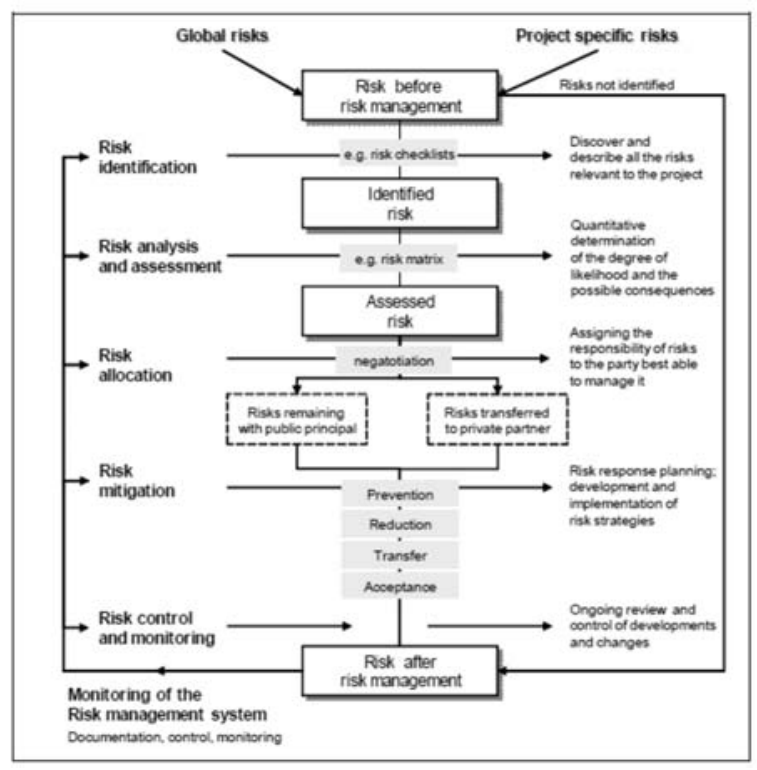

Chart 1 - Monitoring of the Risk Management System

\section{FINANCING OF PPPs}

India has seen rapid growth in recent years in its program of infrastructure public-private partnerships (PPPs). Despite the surge in demand for finance, local financial markets coped well over the period to 2007-and even offered better terms as they became more used to the PPP model. But areas of possible concern have developed. Gearing has increased signifi-cantly, and financing terms mean that PPPs are more exposed to interest rate volatility- causes for concern in a period of rising rates and reduced liquidity. Further growth in PPPs will likely require a broadening of the sources of financing once the present financial market turmoil has lessened. Addressing these concerns will call for policy reforms to capital markets and concession frameworks.

In 1995-2007 senior debt accounted for 68 percent of project financing on average. The rest took the form of equity (25 percent), subordi-nated debt (3 percent), and government grants (4 percent), typically “viability gap” grants provided during construction to PPPs deemed economically desirable but not financially viable.

Of the senior debt, about 70 percent was provided by commercial banks, four-fifths of this by public sector banks. The rest of the total debt financ-ing came from institutional lenders (around 23 percent), with 5 percent provided by the Interna-tional Finance Corporation. Bond markets were used sparingly. The use of subordinated debt also remains limited. Its use has become more common, however, particularly in the road sector, which has the largest number of projects and the greatest acceptance by financial markets. But most of the subordinated debt has been provided by the senior lenders themselves. On the equity side, more than 80 percent came from project developers, with the next largest contributor being the public sector. Strategic investors made direct equity investments in the special-purpose vehicles established to implement the PPPs for only nine projects in the sample. These investments totalled almost $\$ 167$ million (6 percent of the total equity), most of it in the airport sector. Equity investments by financial institutions provided the rest.

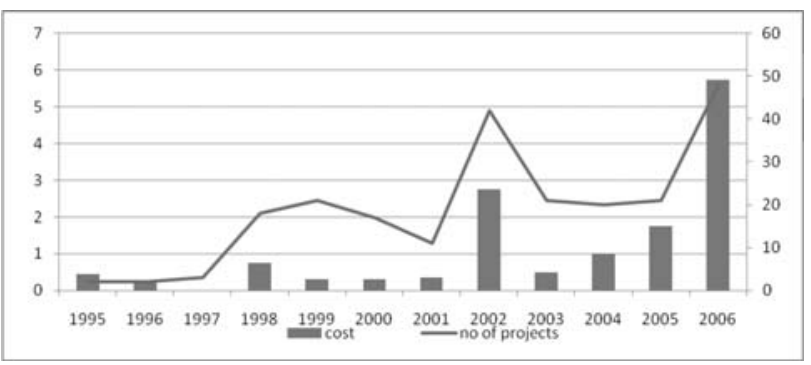

Graph 2 - Growth of PPP Projects in India

\section{EVOLVINGFINANCIALSTRUCTURES}

In recent years the role of senior debt has grown while the share of equity has declined, leading to rising debt-equity ratios. One explana-tion for this trend is that commercial banks have become more comfortable with PPPs, particularly in the road sector, and are therefore willing to have senior debt make up a larger share of project financing.

There is also evidence suggesting that projects with viability gap grants have higher gearing than those without them. While the evidence is inconclusive, there are some indications that lenders and devel-opers view grants as substituting for the equity infusion needed during construction. The few projects involving a negative granta payment by the PPP to the government-also have a higher ratio of senior debt to equity, suggesting that these payments are being financed by debt borrowed by the PPP project.

Should high gearing and the replacement of equity by grants be a concern? Some observers (such as Ehrhardt and Irwin 2004) have argued that greater leverage means a higher likelihood of bankruptcy - and thus a higher likelihood of government bailout to avoid the adverse consequences of bankruptcy, both actual and perceived. In addition, low equity contributions make it easier for develop-ers to achieve a target return from the margin on construction and reduce their long-term interest in the project.

In India the typical concession terms encour-age the use of debt over equity. In the highway sector, for example, the contracting agency must compensate the contractor if the contract ends early, even if the termination is due to a breach of the contractor's own obligations or an event of force 

(PPP) MODEL: A CASE STUDY OF RAJIV GANDHI INTERNATIONAL AIRPORT (RGIA) LTD, HYDERABAD.

majeure. In these cases the compensation is partial, with lenders typically being repaid in full or in large part while shareholders get noth-ing. Linking termination payments to debt, while common around the world, can encourage higher gearing, which in turn may increase projects' financial vulnerability.

Some countries put limits on the ratio of debt to equity. But restricting an investor's ability to choose its capital structure can increase the cost of capital, prevent companies from reaping tax advantages associated with particular types of financing, and impose a monitoring burden on the government. Alternatively, India could consider a different basis for termination payments, reduc-ing the incentive to use debt embedded in the termination clauses of its model concessions.

\section{EFFECTOFDEBTFINANCING}

Despite some volatility, average spreads on debt to PPP projects have declined significantly in recent years. This does not reflect trends in Indian corporate bond spreads, which increased in 2006 and 2007. While many factors may be involved, the decline in spreads is probably due to the financial markets' growing acceptance and understanding of PPPs as more have come on line and provided an operational track record, particu-larly in the road sector. On the negative side, the tenor of debt has increased little, averaging around 14-15 years in the past few years. In addition, loans in India have shown a trend toward shorter reset periods. Although the loans are long term, rates are reset at predefined intervals. PPP projects generally do not have reve-nues that are linked to interest rates. There are

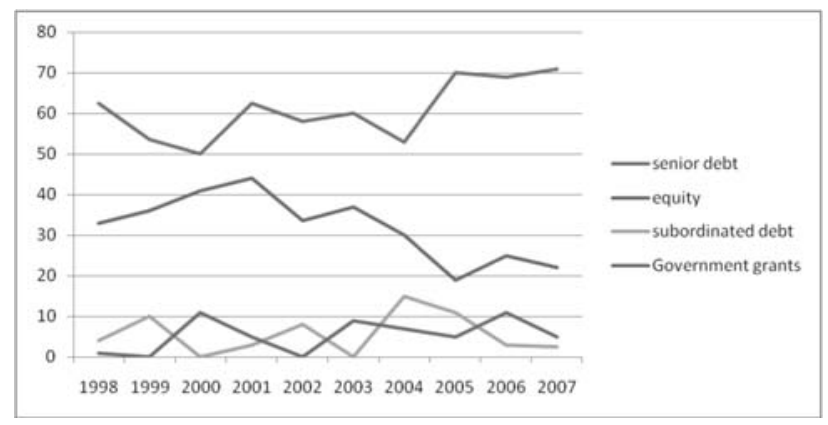

Graph 3 - Debt-Equity Ratios of Indian PPP Projects

\section{CASESTUDY: GMR'SRAJIVGANDHIINTERNATIONAL AIRPORT,HYDERABAD}

GMR Hyderabad International Airport Limited (GHIAL) was formed to design, finance, build, operate and maintain the Greenfield Rajiv Gandhi International Airport (RGIA) on
5,495 acres in Shamshabad, located $25 \mathrm{~km}$ from the city centre of Hyderabad. The airport is the first Public Private Partnership in the Indian airport infrastructure sector between GMR Infrastructure Ltd. (63\%), Malaysian Airports Holdings Berhad (11\%), Airports Authority of India (13\%) and Government of Andhra Pradesh (13\%).

The airport which opened to commercial traffic from 23rd March, 2008, provides world-class facilities and infrastructure, in accordance with ICAO standards and practices to handle large aircraft and international traffic. Its integrated domestic and international terminals are equipped with 12 contact boarding bridges, 30 remote stands, Common User Terminal Equipment (CUTE), self check-in kiosks (Common User Self Service- CUSS) and 46 immigration counters. It also incorporates modern IT systems including Flight Information Display Screens, Baggage Handling System (BHS), and Airport Operational Database (AODB) technology for the first time in India. RGIA is the first Indian airport to have the Airport Operations Control Centre which acts as the nerve centre for all within the airport.

The airport provides two animal quarantine stations. The first quarantine station is located at the international arrivals and the second, in the Cargo Satellite building. GMR Hyderabad International Airport Ltd. (GHIAL) provided 10 sq. metre space at International arrivals and 40 sq. mtr space at the Cargo Satellite Building for these stations. The Animal Quarantine facility will not only facilitate the clearance of pet dogs and cats, after conducting the necessary quarantine tests, but will also help the livestock and pharmaceutical industry for import of lab animals etc. The airport is designed to handle 12 million passengers per annum in the initial phase and more than 100,000 metric tonnes of cargo per annum. In the final stage, it will be able to cater over 40 million passengers per annum and 1 million tonnes of cargo.

The major access points to the airport are from the National Highway NH-7 and Outer Ring Road (ORR) from the west side and Srisailam State Highway on the Eastern side. Also a first of its kind $11.6 \mathrm{~km}$ long elevated expressway is being constructed to enable passengers to reach from the city centre to the expanded six lanes $\mathrm{NH}-7$ road, and arrive at the airport within 30 minutes. Besides these, Multi-Modal Transportation System (MMTS), Mono Rail Transport System (MRTS) and other alternative modes of transport are being actively explored in collaboration with the state government. Located strategically at the geographical centre of India, Hyderabad is within a two hour flying radius 

(PPP) MODEL: A CASE STUDY OF RAJIV GANDHI INTERNATIONAL AIRPORT (RGIA) LTD, HYDERABAD.

to all the major cities in India and a four hours radius to all the major cities in the Middle East and South East Asia. The city therefore holds tremendous potential to emerge as one of the main air travel hubs in India and the critical destination-and-transit point for travel between the East and the West. Currently, there are 12 foreign and 10 domestic airlines operating from Hyderabad which fly to over 35 destinations. In addition, Lufthansa Cargo also operates a weekly freighter service from Frankfurt via Mumbai.

The Rajiv Gandhi International Airport at Hyderabad is also well poised to establish the city of Hyderabad prominently on the global aviation map thus contributing to the prosperity, growth and economic development of the region. It is the first airport in the world to be awarded the Leadership Energy and Environment Design (LEED) silver rating for its eco-friendly design. It has also been nominated as winner for the 'Outstanding Concrete Structure' of Andhra Pradesh by the Indian Concrete Institute. Further, GMR Varalakshmi Foundation - the Corporate Social Responsibility Arm of the Group, has won the ORBIS award for its exemplary service in enhancing the quality of life of the communities living around the RGIA.

\section{RATIONAL OF CLOSING THE EXISTING (OLD) AIRPORTAND CONSTRUCTION OF NEW AIRPORT}

$\S$ Air Traffic Forecasting: Since there has been a huge increase in air traffic at the old Begumpet airport which the airport cannot handle and also resulted in thinking of an alternative for construction of new airport.

$\S$ Density of population in adjoining areas: The old airport as it is in the heart of the city and all the area surrounding the airport is densely populated and more over the planes have been flying over the building due to which there are more chances of accidents.

$\S$ Majority of lands belongs to government: The main reasons for starting new airport is in order develop the old airport land acquisition has been a issue since the lands adjoining the old airport are private lands. So in case of new airport the lands belong to the government and there is no problem of land acquisition.

$\S$ Outer Ring Road (ORR): In case of old airports the has there always there has been huge traffic jams due which the is lot of congestion in city, the new airport is having a connectivity of outer ring road due to which the approach to airport is easy and the will be no traffic congestions.
$\S$ Train Service Feasibility was done during Airport Execution: At the time of the airport planning stage itself, planning was done for the metro train services due to which there will be good connectivity for the airport.

$\S$ Exclusivity Clause: The state government has signed with GMR Hyderabad International Airport Ltd that there would be no airport in a $150-\mathrm{km}$ radius of the Shamshabad Airport. This would mean there would be no airports at Mahbubnagar, Warangal, Khammam, Nalgonda, Karimnagar and Medak.

\section{CONCLUSION}

- There has been consistent increase of contribution of infrastructure to Indian GDP.

- Initially it contributed only 5\% of GDP in 2006 and 2007 but later it increased to $7.5 \%$.

- $\quad$ PPP model played a major role in the development of infrastructure project and as this model has many advantages to it, Government is going for a PPP model in each and every project.

- Indian Government has adopted PPP model in most of its infrastructure sectors.

- There are various types of risk associated with PPP project and each risk has a different risk mitigation strategy to it.

- $\quad$ RGIA is a better solution for catering the growing international and national traffic but still questions remains to be answered behind closing of old Begumpet airport.

- All the financial parameters (Refer Appendix - 1) suggest the robust growth after the commissioning of the Airport.

\begin{tabular}{|r|c|c|c|c|}
\hline Year & International & Domestic & Others & Total \\
2009 & 14000 & 30000 & 8000 & 52000 \\
\hline 2012 & 16000 & 34000 & 12000 & 62000 \\
\hline
\end{tabular}

TABLE 3 - FORECASTED ANNUAL AIR TRAFFIC MOVEMENT

\begin{tabular}{|r|c|cc|r|}
\hline Year & Domestic & International & Connecting & Total \\
$\mathbf{2 0 0 8}$ & 2313 & 1326 & 128 & $\mathbf{3 7 6 7}$ \\
\hline $\mathbf{2 0 1 2}$ & 2961 & 1706 & 350 & $\mathbf{5 0 1 7}$ \\
\hline $\mathbf{2 0 1 7}$ & 3962 & 2177 & 793 & $\mathbf{6 9 3 2}$ \\
\hline $\mathbf{2 0 2 1}$ & 5003 & 2646 & 1349 & $\mathbf{8 9 9 8}$ \\
\hline
\end{tabular}

TABLE 4 - FORECASTED ANNUAL PASSENGER MOVEMENT 
FINANCING AND RISK MANAGEMENT TECHNIQUES IN GREEN FIELD PROJECTS UNDER PUBLIC, PRIVATE PARTNERSHIP (PPP) MODEL: A CASE STUDY OF RAJIV GANDHI INTERNATIONAL AIRPORT (RGIA) LTD, HYDERABAD.

\begin{tabular}{|c|c|}
\hline YEAR & NET REVENUE \\
\hline $2006-07$ & 316.02 \\
$2007-08$ & 473.42 \\
\hline $2008-09$ & 1206.24 \\
\hline
\end{tabular}

TABLE 5 - NET REVENUE

\begin{tabular}{|c|c|}
\hline YEAR & CONCESSIONAIRE SHARE \\
\hline $2006-07$ & 271.98 \\
$2007-08$ & 403.13 \\
\hline $2008-09$ & 456.97 \\
\hline
\end{tabular}

TABLE 6 - REVENUE SHARE PAYABLE TO CONCESSIONAIRE

Note - Concessionaire share in Crores (1 Crore = 10million)

\section{References:}

1. Blocher, Edward J., Chen, and Lin. (1998). Cost Management: A Strategic Emphasis. Boston, MA: McGrawHill.

2. Horngren, Charles T., Foster, and Datar. (1999). Cost Accounting: A Managerial Emphasis, 10th ed. Upper Saddle River, NJ: Prentice Hall.

3. Raiborn, Cecily A., Barfield, and Kinney. (1966). Insights: Readings in Managerial Accounting, 2nd ed. St. Paul, MN: West.

4. Schick, Allen, ed. (1980). Perspectives on Budgeting. Washington, DC: American Society for Public Administration.

5. Harrington, Scott E., Niehus, Gregory R. (2007). Risk Management and insurance, $2^{\text {nd }}$. Ed. New York: McGrawHill.

6. Willson, James D. (1995). Budgeting and Profit Planning Manual. Boston, MA: Warren, Gorham, Lamont.

7. GMR Infrastructure Limited 13th Annual Report 20082009.

8. Concession Agreement for the Development, operation and maintenance of Hyderabad international Airport between Ministry of Civil Aviation, Government of India and Hyderabad International Airport.

9. Closing the Infrastructure Gap: Role of Public Private Partnership-A Deloitte Research Study.
10. Guidelines-Financial support to Public Private Partnership in Infrastructure.

11. HIS Global Insight-Importance of Infrastructure Construction in India.

12. GMR Infrastructure Limited 11th Annual Report 20062007.

13. Cygnus Management Insight-Infrastructure.

14. GMR Infrastructure Limited-Audited Financial Results for the Quarter/Year ended March 31, 2008.

15. GMR Infrastructure Limited-Audited Financial Results for the Quarter/Year ended March 31, 2007.

16. GMR Infrastructure Limited-Audited Financial Results for the Quarter/Year ended March 31, 2006.

17. Assocham Eco pulse study April 2009.

18. Eleventh Five Year plan, Volume III, Planning Commission of India.

19. 16th Annual European Real Estate Society Conference Highlights.

20. Financial Support to PPP in Infrastructure, published by The Secretariat for the Committee of Infrastructure.

21. Managing Fiscal Risks from PPP's National PPP/PFI Workshop, Elmina Hotel November 21-22, 2008.

22. Infrastructure Finance-An Indian Perspective by Abhijit Dutta.

23. PPP Nodal Officers Workshop March 23, 2009. 